\title{
Clinical Utility of Histological Examination of Gastric Ulcer Margin to Diagnose Helicobacter Pylori Infection
}

\author{
Mu-Shien Lee, MD; Chi-Ju Yeh¹, MD; Hsing-Yu Chen², MD; \\ Yung-Kuan Tsou, MD; Cheng-Hui Lin, MD; Jau-Min Lien, MD \\ Background: To investigate the effectiveness of histological examination of ulcer margins \\ (HEUM) in detecting Helicobacter pylori (H. pylori) infection in patients \\ with non-bleeding gastric ulcers (GUs). \\ Methods: A retrospective study included 284 patients with GU undergoing concomi- \\ tant HEUM and rapid urease test (RUT) to detect $H$. pylori infection between \\ January 2005 and December 2006. The slides were reviewed by an experi- \\ enced pathologist (revised HEUM) in the 52 patients with inconsistent \\ results on the initial HEUM and RUT. $H$. pylori infection was defined as a \\ postive RUT and/or revised HEUM. Detection rates of $H$. pylori infection for \\ HEUM and RUT were calculated accordingly. In patients with $H$. pylori \\ infection, several parameters including ulcer characteristics and pathological \\ findings were compared between patients with negative and positive \\ (revised) HEUM. \\ Results: $\quad$ A total of $164(57.7 \%)$ patients had positive results of $H$. pylori infection. \\ The overall detection rates of $H$. pylori infection on the initial HEUM, \\ revised HEUM and RUT were 78.0\% (128/164), 89.0\% (146/164), and \\ $94.5 \%$ (155/164), respectively. For antrum ulcers, the respective detection \\ rates were $81.0 \%(85 / 105), 92.4 \%(97 / 105)$, and $93.3 \%$ (98/105), for angulus \\ ulcers, $78.6 \%(22 / 28), 85.7 \%(24 / 28)$, and $100 \%$ (28/28), and for proximal \\ stomach ulcers, $61.9 \%(13 / 21), 81.0 \%(17 / 21)$, and $90.4 \%(19 / 21)$. In \\ patients with $H$. pylori infection, gastric malignancy was more frequently \\ observed in patients with false negative than true positive HEUMs. \\ Conclusions: HEUM might be not sensitive enough for diagnosing $H$. pylori in patients \\ with GU. It was especially insensitive when the ulcers were in the proximal \\ stomach, the ulcers were malignant, or the slides were interpreted by pathol- \\ ogists in a rotating manner.
}

(Chang Gung Med J 2012;35:240-6)

Key words: histology of gastric ulcer biopsy, helicobacter pylori infection, rapid urease test

$H$

elicobacter pylori $(H$. pylori) infection is a major etiological cause of peptic ulcers. ${ }^{(1,2)}$ The eradication of this pathogen reduces ulcer recurrence and the methods for doing this are cost effective. ${ }^{(3,4)}$ Therefore, the development of accurate tests to detect this organism is important. Current guidelines

\footnotetext{
From the Department of Gastroenterology and Hepatology; 'Department of Pathology; ${ }^{2}$ Department of Traditional Chinese Medicine, Chang Gung Memorial Hospital at Linkou, Chang Gung University College of Medicine, Taoyuan, Taiwan.

Received: May 18, 2011; Accepted: Nov. 14, 2011

Correspondence to: Dr. Yung-Kuan Tsou, Department of Hepato-Gastroenterology, Chang Gung Memorial Hospital at Linkou. 5, Fusing St., Gueishan Township, Taoyuan County 333, Taiwan (R.O.C.) Tel: 886-3-3281200 ext. 8108; Fax: 886-3-3272236;

E-mail: flying3454@xuite.net
} 
suggest that $H$. pylori can be diagnosed by several invasive and noninvasive methods. ${ }^{(5)}$ Invasive methods are biopsy-based tests which require endoscopy, including a rapid urease test (RUT), histology, culture, and polymerase chain reaction. When endoscopy is indicated, a rapid RUT is generally the test of choice because of its simplicity, low cost, and relatively rapid results. ${ }^{(5-8)}$

For histological examination to detect $H$. pylori, biopsy specimens should be obtained from a nonulcer part of the stomach. ${ }^{(5,9)}$ In patients with gastric ulcers (GUs), however, multiple biopsy specimens must be obtained from the ulcer margin to distinguish benign from malignant ulcers. ${ }^{(10,11)} \mathrm{H}$. pylori status has been recommended to be included in the diagnostic phrase if they are detected in any of the biopsy specimens. ${ }^{(9)}$ Therefore, this histological examination of ulcer margins (HEUM) will also reveal $H$. pylori infection in patients with GU, but there few studies have evaluated the accuracy of this test. Despite a lack of evidence in the literature, using HEUM to diagnose $H$. pylori infection in GU patients has been a common practice in Taiwan because of health insurance reimbursement restrictions. ${ }^{(12)}$ Currently, the only test for $H$. pylori infection which is paid for by insurance is the urea breath test performed after anti-H. pylori therapy for patients with peptic ulcers documented on endoscopy. ${ }^{(13)}$ Therefore, the aim of this study was to evaluate the effectiveness of HEUM in detecting $H$. pylori infection in GU patients.

\section{METHODS}

\section{Patients}

In a 2-year period between 2005 and 2006, 1615 patients had endoscopically diagnosed GUs at Chang Gung Memorial Hospital (Division of Digestive Therapeutic Endoscopy; Linkou Center, Taipei and Taoyuan Branches). Among them, 284 patients undergoing concomitant GU biopsy and RUT were enrolled in this study. Follow-up endoscopic procedures to document ulcer healing were not included in the study. Patients with the following criteria were also excluded: age younger than 20 years, gastrectomy prior to endoscopy, prominent ulcerative mass on endoscopy, active ulcer bleeding, and intake of antibiotics or proton pump inhibitors within 2 weeks before endoscopy. Patient data and endoscopic find- ings, as well as pathologic reports were collected and analyzed retrospectively.

\section{Gastric ulcers}

A GU was defined by endoscopic findings as a mucosal ulceration in the stomach regardless of its size. GUs were classified by location in the antrum, angulus, or proximal stomach (including the body, fundus, and cardia). Patients with ulcers at more than 2 locations $(n=39)$ were classified according to the biopsied ulcer. The largest or morphologically abnormal ulcer was usually chosen as the biopsy site. In patients with more than one ulcer $(n=141)$, the ulcer size was calculated according to the biopsied ulcer.

\section{Rapid urease test and ulcer biopsy}

Pronto Dry (Medical Instruments Corporation, ZI Nord, Brignais, France), a biopsy urease test, was used for the RUT. The clinician and endoscopist varied. The RUT was carried out only upon clinician's request before the endoscopy. It was our practice to obtain two specimens from the nonulcer part of the antrum for the RUT. The tests were carried out until positive results were obtained or for up to one hour. A color change from yellow to pink was considered a criterion for the presence of $H$. pylori infection.

Biopsy specimens for histological examination were obtained from the GU margin (that is, HEUM). The mean number of specimens was 4.2 (range from 2-9). The biopsy specimens were histologically examined by hematoxylin and eosin $(\mathrm{H} \& \mathrm{E})$ staining in all cases. These $\mathrm{H} \& \mathrm{E}$-stained slides were interpreted by faculty members of the Department of Pathology in a rotating manner. The primary goal of the ulcer biopsy was to exclude gastric malignancy, but $H$. pylori status was also included in the pathologic reports (initial HEUM) in all cases. In 7 patients, histopathology showed the GUs were malignant.

When the results of the initial HEUM and RUT were inconsistent, an experienced pathologist (Yeh CJ) who was blinded to the results of the RUT and initial HEUM reviewed all $\mathrm{H} \&$ E-stained slides to diagnose $H$. pylori infection (revised HEUM).

\section{Definition of $H$. pylori infection and statistical analysis}

For the purpose of analysis, patients with $H$. pylori infection were defined as follows: (1) The 
RUT and revised HEUM were both positive ( $\mathrm{n}=$ 137); (2) Both the initial and revised HEUM were positive and the RUT was negative $(n=9)$; (3) The RUT was positive and both the initial and revised HEUM were negative $(\mathrm{n}=18)$ (Table 1$)$. Accordingly, there were $164(57.7 \%)$ patients with $H$. pylori infection in this study.

Quantitative data were expressed as mean \pm standard deviation. Differences were compared using the two-sample $t$-test for continuous variables and the $\chi^{2}$-test or Fisher's exact test for categorical variables. The analyses were performed with the statistical software SPSS 18.0 version for Windows. A $p$ value of $<0.05$ was considered statistically significant.

\section{Ethics}

The study protocol was approved by the ethics committee at Chang Gung Memorial Hospital (IRB No: 98-2704B).

\section{RESULTS}

A total of 284 patients with GUs were analyzed. The mean age of the patients was $57.6 \pm 15.6$ years

Table 1. Histological Examination of Ulcer Margin and Rapid Urease Test for Detection of H. Pylori Infection in Patients with Gastric Ulcers

\begin{tabular}{lccc}
\hline Test results & $\begin{array}{c}\text { Initial HEUM } \\
(\mathrm{n}=284)\end{array}$ & $\begin{array}{c}\text { Revised HEUM } \\
(\mathrm{n}=284)\end{array}$ \\
\hline HEUM (+) & RUT (+) & 119 & 137 \\
HEUM (+) & RUT (-) & 16 & 9 \\
HEUM (-) & RUT (+) & 36 & 18 \\
HEUM (-) & RUT (-) & 113 & 120 \\
\hline
\end{tabular}

Abbreviations: HEUM: histological examination of ulcer margin; RUT: rapid urease test. (range, 27-91 years); $57.4 \%$ of them were men. The size of the GUs was $8.5 \pm 6.1 \mathrm{~mm}$ (range, 2-30 $\mathrm{mm})$.

\section{Initial HEUM and RUT}

The results of the initial HEUM and RUT (Table 1) were consistent in $232(81.7 \%)$ patients: both tests were positive in 119 patients and both were negative in 113 patients. In the remaining $52(18.3 \%)$ patients, the HEUM was positive and RUT was negative in 16 patients, and the HEUM was negative and RUT was positive in 36 patients.

\section{Revised HEUM and RUT}

Results of the revised HEUM and RUT are shown in Table 1. After pathological review of the 52 patients with initially inconsistent results between HEUM and RUT, 9 (17.3\%) cases remained positive and $18(34.6 \%)$ remained negative for $H$. pylori infection. In the remaining $25(48.1 \%)$ cases, The results turned out to be consistent with those of the RUT (Table 1) in 7 of the 16 patients with initially positive HEUMs and 18 of the 36 patients with initially negative HEUMs. Accordingly, the revised HEUM and RUT were consistent in 257 (90.5\%) patients: both were positive in 137 patients and both were negative in 120 patients. The HEUM remained positive and the RUT was negative in 9 patients. The HEUM remained negative and the RUT was positive in 18 patients.

\section{Detection rates of HEUM and RUT}

Detection rates of $H$. pylori infection for each test are shown in Table 2. According to the definition of the study, $164(57.7 \%)$ of the 284 patients were positive for $H$. pylori infection. The detection rates of $H$. pylori infection for the initial HEUM, revised HEUM, and RUT were $78.0 \%$ (128/164), 89.0\% (146/164), and 94.5\% (155/164), respectively.

Table 2. Detection Rates of H. Pylori Infection at Different Locations

\begin{tabular}{|c|c|c|c|c|c|c|c|c|c|c|c|c|}
\hline & \multicolumn{3}{|c|}{$\begin{array}{l}\text { Overall } \\
(\mathrm{n}=164)\end{array}$} & \multicolumn{3}{|c|}{$\begin{array}{l}\text { Antrum ulcers } \\
\quad(\mathrm{n}=105)\end{array}$} & \multicolumn{3}{|c|}{$\begin{array}{l}\text { Angulus ulcers } \\
\quad(\mathrm{n}=28)\end{array}$} & \multicolumn{3}{|c|}{$\begin{array}{l}\text { Proximal stomach ulcers } \\
\qquad(\mathrm{n}=21)\end{array}$} \\
\hline & \multicolumn{2}{|c|}{ HEUM } & \multirow{2}{*}{ RUT } & \multicolumn{2}{|c|}{ HEUM } & \multirow{2}{*}{ RUT } & \multicolumn{2}{|c|}{ HEUM } & \multirow{2}{*}{ RUT } & \multicolumn{2}{|c|}{ HEUM } & \multirow{2}{*}{ RUT } \\
\hline & Initial & Revised & & Initial & Revised & & Initial & Revised & & Initial & Revised & \\
\hline Detection Rate & $78.0 \%$ & $89.0 \%$ & $94.5 \%$ & $81.0 \%$ & $92.4 \%$ & $93.3 \%$ & $78.6 \%$ & $85.7 \%$ & $100 \%$ & $61.9 \%$ & $81.0 \%$ & $90.4 \%$ \\
\hline (n) & (128) & $(146)$ & (155) & (85) & (97) & (98) & (22) & (24) & (28) & (13) & (17) & (19) \\
\hline
\end{tabular}

Abbreviations: HEUM: histological examination of ulcer margin; RUT: rapid urease test. 


\section{Detection rates of HEUM and RUT according to ulcer location}

The results according to ulcer location are shown in Table 2. A total of 16 patients were excluded for analysis because the ulcer location was unclear in the chart records $(n=2)$ or biopsy samples were obtained from 2 or more ulcer locations and were stored in a container for pathological examination $(n=14)$. As a result, 268 patients were included in this analysis. One hundred and ninety-seven $(73.5 \%)$ patients had antrum ulcers, 35 (13.1\%) had angulus ulcers, and $36(13.4 \%)$ had proximal stomach ulcers. For antrum ulcers, 105 (53.3\%) patients had $H$. pylori infection. The detection rates for the initial HEUM, revised HEUM, and RUT were $81.0 \%$ (85/105), 92.4\% (97/105), and 93.3\% (98/105), respectively. For angulus ulcers, $28(80.0 \%)$ patients had $H$. pylori infection. The detection rates for the initial HEUM, revised HEUM, and RUT were $78.6 \%$ (22/28), $85.7 \%(24 / 28)$, and $100 \%$ (28/28), respectively. For proximal stomach ulcers, $21(58.3 \%)$ patients had $H$. pylori infection. The detection rates for the initial HEUM, revised HEUM, and RUT were $61.9 \%(13 / 21), 81.0 \%$ (17/21), and 90.4\% (19/21), respectively.

\section{Detection rates of HEUM according to number of biopsied specimens}

The detection rate of $H$. pylori infection for the revised HEUM was $90.9 \%$ (50/55) in patients with 2 to 3 biopsy specimens, and $88.1 \%(96 / 109)$ in patients with 4 or more biopsy specimens. All 7 patients with malignant ulcers underwent 4 or more biopsies. When the patients with gastric malignancy were excluded from analysis, the detection rate on the revised HEUM was $91.7 \%$ (100/109) in patients with 4 or more biopsy specimens.

\section{Factors attributed to false negative HEUM}

Among the 164 patients with $H$. pylori infection, $18(11 \%)$ were negative (false negative) and $146(89 \%)$ were positive (true positive) for H. pylori infection according to the revised HEUM. Age, sex, ulcer location and size, number of biopsy specimens, and pathological findings including malignancy, intestinal metaplasia and atrophy were compared between patients with false negative and true positive HEUMs (Table 3). Only malignancy was found significantly more prevalent in patients with false
Table 3. Comparisons Between Patients with False Negative and True Positive Histological Examinations of the Gastric Ulcer Margin among the 164 Patients with $H$. Pylori Infection.

\begin{tabular}{lccc}
\hline & $\begin{array}{c}\text { False negative } \\
\text { HEUM }(\mathrm{n}=18)\end{array}$ & $\begin{array}{c}\text { True positive } \\
\text { HEUM }(\mathrm{n}=146)\end{array}$ & $p$ value \\
\hline Age & $60.1 \pm 18.0$ & $57.3 \pm 14.5$ & 0.45 \\
Sex (women) & $6(33.3 \%)$ & $51(34.9 \%)$ & 0.89 \\
Ulcer location* (A/G/B) & $8 / 4 / 4$ & $97 / 24 / 17$ & 0.29 \\
Ulcer size & $11.7 \pm 7.2$ & $9.0 \pm 6.4$ & 0.11 \\
Number of biopsies & $4.3 \pm 1.3$ & $4.2 \pm 1.5$ & 0.69 \\
Malignant ulcers & $4(22.2 \%)$ & 0 & $<0.001$ \\
Intestinal metaplasia & $4(22.2 \%)$ & $27(18.5 \%)$ & 0.75 \\
Gastric atrophy & $1(5.6 \%)$ & 0 & 0.11 \\
\hline
\end{tabular}

*: Two patients with false negative and 8 patients with true positive HEUMs, were excluded from analysis because of unidentifiable ulcer locations.

Abbreviations: HEUM: histological examination of ulcer margin; A: antrum; G: angulus; B: proximal stomach including body, fundus, and cardia.

negative HEUMs than in patients with true positive HEUMs.

\section{DISCUSSION}

When endoscopy is indicated, RUT or histopathologic interpretation of $\mathrm{H} \&$ E-stained biopsy specimens from a nonulcer part of the stomach is generally the test of choice to detect $H$. pylori. ${ }^{(5,14,15)}$ There is no study suggesting the use of HEUM. In Taiwan, however, HEUM is often used for diagnosing $H$. pylori infection in patients with GUs because of reimbursement restrictions from health insurance. ${ }^{(12,13)}$ This study showed that the revised HEUM was less sensitive $(89.0 \%)$ to detect $H$. pylori infection than the RUT $(94.5 \%)$. The detection rate was even lower $(78.0 \%)$ when the slides were interpreted by pathologists in a rotating manner. Furthermore, we found that HEUM was least sensitive for patients with proximal stomach ulcers. This result may reflect the fact that the density of $H$. pylori is lower in the gastric body than in the antrum, and an $\mathrm{H} \& \mathrm{E}$ stain is less sensitive in detecting $H$. pylori of specimens containing only small numbers of organisms..$^{(16,17)}$ 
Special stains such as modified Giemsa, Warthin-Starry, Genta, or specific immune stains, which are reported to have higher diagnostic sensitivity than that of an $\mathrm{H} \& \mathrm{E}$ stain to detect $H$. pylori in nonulcer specimens, were not used in this study. ${ }^{(15,18,19)}$ However, the standard H \& E stain is excellent to determine histological inflammation or malignancy, as well as $H$. pylori status, if adequate numbers of organisms are present in specimens. ${ }^{(9)}$ Since the primary goal of ulcer biopsy is to detect malignancy, the aim of this study was to demonstrate the accuracty of this routine practice (ulcer biopsy) for detecting $H$. pylori infection in patients with GUs. Therefore, we did not evaluate the accuracy of HEUM by special stains.

Kolts et al. reported that interpretation by an experienced pathologist is significantly better and may present an advantage over analysis by rotating pathologists in evaluating $\mathrm{H} \&$ E-stained biopsy specimens. ${ }^{(14)}$ In the present study, the initial HEUMs were interpreted by pathologists in a routine rotating manner. After review of the slides by an experienced pathologist, 25 (48.1\%) of the 52 initially inconsistent results on the HEUM and RUT turned out to be consistent. Consequently, the detection rates of $H$. pylori infection by HEUM increased from $78.0 \%$ to $89.0 \%$. This result was in agreement with that of a previous report and suggested that $\mathrm{H} \&$ E-stained biopsy specimens should be interpreted by an experienced pathologist. ${ }^{(14)}$

Eighteen (11.0\%) of the 164 patients had false negative tests on the revised HEUM. We analyzed several parameters and found that only malignancy was more prevalent in patients with negative than positive HEUMs. In fact, none of the 7 patients with gastric malignancy had a positive HEUM, compared with 4 of the 7 patients with a positive RUT. Therefore, HEUMs may be unreliable for diagnostic $H$. pylori infection in patients with malignant gastric ulcers. Instead, the upper body greater curvature side has been suggested to be the most sensitive and specific biopsy site for detecting $H$. pylori in patients with gastric cancers. ${ }^{(20)}$

Genta et al. reported that that two antral biopsy specimens (one from the lesser and one from the greater curvature of the nonulcer part) yielded virtually $100 \%$ sensitivity for detecting $H$. pylori infection. ${ }^{(17)}$ Specimens from the corpus did not increase the diagnostic yield unless extensive intestinal meta- plasia was present in the antrum. For HEUM, the results of the present study showed that the detection rates of $H$. pylori infection were comparable between using 2 to 3 biopsy specimens and 4 or more specimens. This result suggests that 2 to 3 biopsy specimens obtained from the ulcer margin may be sensitive enough to detect $H$. pylori infection.

The major limitation of this study was that the definition of patients with $H$. pylori infection was somewhat arbitrary. This is mainly because there is no single test that can be considered the gold standard for the diagnosis of H. pylori. ${ }^{(5)}$ In this study, however, most (137 of $164,83.5 \%$ ) patients were positive on both the revised HEUM and RUT. Nine (5.5\%) patients were diagnosed with $H$. pylori infection based on only the revised HEUM. However, both of the two pathologists agreed that $H$. pylori were present in the biopsy specimens. In the remaining $18(11.0 \%)$ patients, $H$. pylori infection was diagnosed only according to a single RUT. However, the specificity of the RUT is reported to be nearly $100 \%{ }^{(6-8,16,21)}$ That is, a false positive RUT is unusual. Therefore, we believed that the definition of patients with $H$. pylori infection in the present study was reasonable.

In conclusion, this report is one of the few studies dealing with HEUM for diagnosing $H$. pylori infection in GU patients. HEUM by $\mathrm{H} \& \mathrm{E}$ stain, a routine test for excluding malignant gastric ulcers, might be not sensitive enough for diagnosing $H$. pylori in GU patients. HEUM was especially insensitive when the ulcers were in proximal stomach and/or when the slides were interpreted by pathologists in a rotating manner. It was also unreliable for patients with malignant gastric ulcers.

\section{REFERENCES}

1. Marshall BJ. Helicobacter pylori. Am J Gastroenterol 1994;89:S116-28.

2. Peura DA. Helicobacter pylori and ulcerogenesis. Am J Med. 1996;100:S19-25.

3. Leodolter A, Kulig M, Brasch H, Meyer-Sabellek W, Willich SN, Malfertheiner P. A meta-analysis comparing eradication, healing and relapse rates in patients with Helicobacter pylori-associated gastric or duodenal ulcer. Aliment Pharmacol Ther 2001;15:1949-58.

4. Ford AC, Delaney BC, Forman D, Moayyedi P. Eradication therapy in Helicobacter pylori positive peptic ulcer disease: systematic review and economic analysis. 
Am J Gastroenterol 2004;99:1833-55.

5. Chey WD, Wong BCY. Practice Parameters Committee of the American College of Gastroenterology. American College of Gastroenterologoy guideline on the management of Helicobacter pylori infection. Am J Gastroenterol 2007;102:1808-25.

6. Cutler AF, Havstad S, Ma CK, Blaser MJ, Perez-Peres GI, Schubert TT. Accuracy of invasive and non-invasive tests to diagnose Helicobacter pylori infection. Gastroenterology 1995;109:136-41.

7. Thijs JC, Van Zwet AA, Thijs WJ, Oey HB, Karrenbeld A, Stellaard F, Luijt DS, Meyer BC, Kleibeuker JH. Diagnostic test for Helicobacter pylori: a prospective evaluation of their accuracy, without selecting a single test as the gold standard. Am J Gastroenterol 1996;91:2125-9.

8. Laine L, Lewin D, Naritoku W, Estrada R, Cohen H. Prospective comparison of commercially available rapid urease test for the diagnosis of Helicobacter pylori. Gastrointest Endosc 1996;44:523-6.

9. Dixon MF, Genta RM, Yardley JH, Correa P. Classification and grading of gastritis. The updated Sydney System. International Workshop on the Histopathology of Gastritis, Houston 1994. Am J Surg Pathol 1996;20:1161-81.

10. Todd JA, Richards CJ, Dixon A, Robinson RJ. Gastric ulcer and malignancy--is there a need for follow-up endoscopy? Aliment Pharmacol Ther 2004;19:989-91.

11. Thomopoulos KC, Melachrinou MP, Mimidis KP, Katsakoulis EC, Margaritis VG, Vagianos CE, Nikolopoulou VN. Gastric ulcers and risk for cancer. Is follow-up necessary for all gastric ulcers? Int J Clin Pract 2004;58:675-7.

12. Ho CY, Chen TS, Chang FY, Lee SD. Rapid urease test from non-ulcer part of stomach is superior to histology from ulcer in detection of Helicobacter pylori infection in patients with gastric ulcer. Hepatogastroenterology 2004;51:1877-80.

13. Bureau of National Health Insurance, Department of Health, Executive Yuan, Taiwan, R.O.C. Available at http://www.nhi.gov.tw/resource/bulletin/2212_W0970012 154-附件.doc

14. Kolts BE, Joseph B, Achem SR, Bianchi T, Monteiro C. Helicobacter pylori detection: a quality and cost analysis. Am J Gastroenterol 1993;88:650-5.

15. Wright CL, Kelly JK. The use of routine special stains for upper gastrointestinal biopsies. Am J Surg Pathol 2006;30:357-61.

16. Woo JS, el-Zimaity HM, Genta RM, Yousfi MM, Graham DY. The best gastric site for obtaining a positive rapid urease test. Helicobacter 1996;1:256-9.

17. Genta RM, Graham DY. Comparison of biopsy sites for the histopathologic diagnosis of Helicobacter pylori: A topographic study of $\mathrm{H}$. pylori density and distribution. Gastrointest Endosc 1994;40:342-5.

18. Megraud F, Lehours P. Helicobacter pylori detection and antimicrobial susceptibility testing. Clin Microbiol Rev 2007;20:280-322.

19. el-Zimaity HM. Accurate diagnosis of Helicobacter pylori with biopsy. Gastroenterol Clin North Am 2000;29:863-9.

20. Kim CG, Choi IJ, Lee JY, Cho SJ, Nam BH, Kook MC, Hong EK, Kim YW. Biopsy site for detecting Helicobacter pylori infection in patients with gastric cancer. J Gastroenterol Hepatol 2009;24:469-74.

21. Bermejo F, Boixeda D, Gisbert JP, Defarges V, Sanz JM, Redondo C, Martini de Argila C, Garcia Plaza A. Rapid urease test utility for Helicobacter pylori infection diagnosis in gastric ulcer disease. Hepatogastroenterology 2002;49:5721-5. 


\title{
胃潰煌邊緣生檢法診斷幽門螺旋桿菌感染之臨床應用
}

\author{
李沐害 葉琦如 ${ }^{1}$ 陳星諭 ${ }^{2}$ 蛁永寬 林政輝 連昭明
}

背景：目前很少有利用胃潰痬邊緣切片以診断幽門螺旋桿菌感染的研究。本研究的目的在 於評估用胃潰瘍邊緣組織切片以診断非出血性胃潰痬患者是否有幽門螺旋桿菌感染 的臨床應用性。

方 法: 本研究爲一回溯性研究, 包含 284 位非出血性胃潰瘍患者。所有患者都同時接受潰 㿑邊緣切片的組織學檢查 (histological examination of ulcer margin, HEUM) 及快速尿素 酶試驗來檢驗其是否有幽門螺旋桿菌的感染。其中有 52 位患者潰瘍邊緣切片的組織 學檢查和快速尿素酶試驗的結果並不一致, 這些患者的病理組織切片則由一位有經 驗的病理科醫師重新判讀 (revised HEUM)。幽門螺旋桿菌感染在本試驗的定義爲病 理組織學檢查陽性及/或快速尿素酶試驗陽性, 據此可計算出個別檢驗法（病理組 織檢查或快速尿素酶試驗) 的診斷正確率。一些變項, 包括年紀、性別、潰瘍位置 及大小、切片數目以及病理組織學發現, 例如是否有惡性細胞、腸上皮化生、及胃 秥膜萎縮等都將在病理組織學檢查幽門螺旋桿菌眞陽性以及傜陰性的患者之間做比 較。

結 果：根據本研究的定義總共有 164 位患者有幽門螺旋桿菌的感染。原始的潰瘍邊緣切片 的組織學檢查 (initial HEUM)，重新判讀的病理組織學檢查 (revised HEUM)，及快速 尿素酶試驗三種不同的檢驗法其幽門螺旋桿菌的檢測率分別爲 78.0\% (128/164), $89.0 \%(146 / 164)$, 以及 $94.5 \%$ (155/164)。對於不同潰瘍部位的分析結果如下：胃賽部 的潰瘍，上述的三種檢查其個別的檢測率分別爲 $81.0 \%(85 / 105), 92.4 \%(97 / 105)$, 以 及 93.3\% (98/105)；胃角處的潰痬，78.6\% (22/28)，85.7\% (24/28)，及 100\% (28/28); 胃近端部的潰瘍, 61.9\% (13/21), 81.0\% (17/21), 及 90.4\% (19/21)。所有統計的變項 中, 只有惡性腫瘤這一項因子在病理組織學檢查幽門螺旋桿菌呈僞陰性的患者明顯 多於病理組織學檢查眞陽性的患者。

結 論: 對於胃潰瘍的患者, 使用潰瘍邊緣切片的組織學檢查來檢測其是否有幽門螺旋桿菌 可能不夠準確, 尤其是發生在胃近端部的潰瘍, 或當病理切片被依常規輪班方式的 病理科醫師判讀時; 另外, 當胃潰瘍爲惡性腫瘤時, 用潰瘍邊緣切片的組織學檢查 來診斷患者是否有幽門螺旋桿菌的感染並不可靠。

(長庚醫誌 2012;35:240-6)

關鍵詞：潰瘍生檢之組織學檢查, 幽門螺旋桿菌感染, 快速尿素酶試驗

長庚醫療財團法人林口長庚紀念醫院 肝膽胃腸科系, 病理科系, 2 中醫科系 ; 長庚大學 醫學院 受文日期：民國100年5月18日；接受刊載：民國100年11月14日

通訊作者: 㱀永寬醫師, 長庚醫療財團法人林口長庚紀念醫院 肝膽胃腸科系。桃園縣333龜山鄉復興街 5 號。

Tel: (03)3281200轉8108; Fax: (03)3272236; E-mail: flying3454@xuite.net 